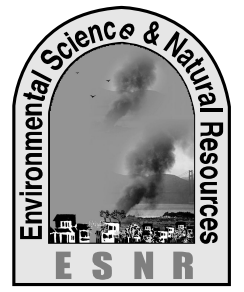

J. Environ. Sci. \& Natural Resources, 5(1): 289-294, 2012

ISSN 1999-7361

\title{
Impacts of Plough Pan on Physical and Chemical Properties of Soil
}

\author{
M. Podder, M. Akter, A. S. M. Saifullah and S. Roy \\ Department of Environmental Science and Resource Management \\ Mawlana Bhashani Science and Technology University, Santosh, Tangail
}

\begin{abstract}
The experiment was carried out to find out the impacts of plough pan on physical and chemical properties of soil. For this purpose, soil samples were collected from two locations of Basail upazila in Tangail dristrict, one having compact plough pan layer in subsoil (site-1) and other one with no plough pan layer (site-2). A survey was also conducted on land use pattern in these areas to get the causes of plough pan formation. In site-1, rice is the dominant crop and in site- 2 shallow rooted crops such as mustard, potato, onion etc. are grown. In site-1, organic $\mathrm{C}, \mathrm{N}, \mathrm{K}, \mathrm{S}, \mathrm{Zn}$ contents were found higher and the concentrations of C, N, K, P, S and Zn decreased from topsoil to lower layers, whereas, concentrations increased to subsoil layer except $\mathrm{P}$ in case of site- 2 .
\end{abstract}

Key words: Chemical property, Physical property, Plough pan

\section{Introduction}

Agriculture is the most important sector of the economy of Bangladesh. Rice (Oryza sativa L.) is the major cereal in Bangladesh. Different types of tools are used in farming for initial land preparation for sowing seed or planting of rice. During such cultivation, sub-soil compaction usually caused by tillage system specifically through mechanical practices. Repeated ploughing may result in plough pan formation in cultivated soil due to use of heavy weight tillage machineries. Plough pans are formed in the same profile under power tiller and country plough treatment mostly in rice field (Islam et al. 2005). The presence of plough pan may influence the physical properties of soil such as soil texture, structure, density, pore space, soil consistency soil color, soil temperature and may also affects soil chemical properties such as soil $\mathrm{pH}$, soil organic matter and availability of soil nutrients. The most direct effect of soil compaction is an increase in the bulk density of soil and destruction of soil structure. Under the conventional tillage system there develops a plough pan layer at about $20 \mathrm{~cm}$ depth of soil that may impose changes in soil physical properties and may lead to a decrease in soil physical quality (Bertolino et al., 2010). Intensive tillage is favorable for the formation of plough pan that decreases soil bulk density and could develop penetration resistance up to tilled depth (Singh et al., 1998). The penetration resistance is high about $8 \mathrm{~cm}$ below average tillage depth due to occurrence of plough pan (Tsimba et al., 1999). Jeyasree and Rao (2005) reported that the percentage of organic matter is higher in shallow tillage with organic amendment than deep tillage with organic amendment. Besides, the highest mineral $\mathrm{N}$ was observed in the shallow ploughed soil where the amount of $\mathrm{P}$ in the soil increased by $11 \%$ at $0-10 \mathrm{~cm}$ soil depth while it decreased by $10 \%$ at $10-20 \mathrm{~cm}$ depth (Feiziene et al., 2006). Thus, the objectives of the study were to find out the possible causes and effects of plough pan layer on physical and chemical properties of soil.

\section{Materials and Method}

\section{Selection of study area}

The study area belongs to Basail upazila of Tangail district where rice cultivation is dominant and sufficient to allow plough pan formation. The geographic location of this area is $24^{\circ} 13^{\prime} \mathrm{N}$ latitude and $90^{\circ} 03^{\prime} \mathrm{E}$ longitude and the total land area is $157.78 \mathrm{~km}^{2}$, belongs to Brahmaputra Floodplain (SRDI, 1994).

\section{Sample collection and processing}

Soil samples were collected from different sites of Hunduli mouza in Basail upzila. Samples were collected using soil core sampler from different depths. Collected samples were placed in sealed polythene bags and labeled indicating date of collection, location and code number of soil sample. The samples were then carried to the laboratory of the Department of Environmental Science and Resource Management (ESRM) at Mawlana Bhashani Science and Technology University (MBSTU), Tangail. Each samples were kept separately on a brown paper and collected samples were dried at room temperature for 15-20 days. The soil samples were kept in a clean polythene bag and then transported to the Soil Resource Development Institute (SRDI) laboratory of Rajshahi areal branch for the analysis of soil $\mathrm{pH}$, organic matter, available phosphorus (P), available 
sulfur $(\mathrm{S})$, total nitrogen $(\mathrm{N})$, potassium $(\mathrm{K})$ and zinc $(\mathrm{Zn})$. A questionnaire survey was also conducted in the areas to know the knowledge of local people about plough pan, the cultural practices that they commonly follow in rice cultivation etc.

\section{Analysis of soil}

The moisture contents of air-dried soil samples were determined by oven-drying known amount of soil in an electric oven at $105^{\circ} \mathrm{C}$ for 24 hours until constant weight was obtained, and the moisture percentage was calculated by the loss of moisture from the samples as described by Huq and Alam (2005). Textural classes were determined by Hydrometer method as outlined by Bouyoucos (1927). Textural classes were determined by Marshall's Triangular Co-ordinates as designed by the United States Department of Agriculture (USDA, 1951). The $\mathrm{pH}$ of soil water suspension was determined using Equiptronics $\mathrm{pH}$ meter as described by Jackson (1967). Organic carbon of the soil samples was determined by wet oxidation method of Walkley and Black as described in Huq and Alam (2005). Organic matter content was determined by ultiplying the percent value of organic carbon with the conventional Van-Bemmelen's factor of 1.724 (Piper, 1950). The nitrogen content of the soil was determined by distilling soil with alkaline potassium permanganate solution (Subhaiah and Asija, 1956). The distillate was collected in $20 \mathrm{ml}$ of $2 \%$ boric acid solution with methyl red and bromocresol green indicator and titrated with $0.02 \mathrm{~N}$ sulphuric acid $\left(\mathrm{H}_{2} \mathrm{SO}_{4}\right)$. The sulfur content of the soil was determined by spectrophotometer at $535 \mathrm{~nm}$. The available $\mathrm{K}$ was determined by flame photometric method after extracting the $\mathrm{K}$ with $1 \mathrm{~N}$ ammonium acetate. The available $\mathrm{P}$ of the soil was determined by spectrophotometer at a wavelength of $890 \mathrm{~nm}$. The soil sample was extracted by Olsen method with 0.5 $\mathrm{M} \mathrm{NaHCO}_{3}$ as outlined by Huq and Alam (2005). Zn was measured by atomic absorption spectrophotometer (AAS) after extracting with DTPA.

\section{Data processing and analysis}

SPSS, Microsoft Excel program were used to process and analyze the data obtained from various analyses.

\section{Results and Discussion}

In site-1, the top-soil has higher concentration of $\mathrm{C}, \mathrm{N}$, $\mathrm{K}, \mathrm{P}, \mathrm{S}$ and $\mathrm{Zn}$ that subsequently decreased in lower layers. In case of site-2, subsoil has higher concentration than top soil. The presence of compact layer in site-1 may cause lower concentration of nutrients in sub soils. On the other hand, the absence of compact layer facilitates the leaching of nutrients (in case of site-2) that result in higher concentration of nutrients in subsoil layer.

\section{Physical properties of soil}

The soil texture of both site- 1 and site- 2 is given in Table 1. The site-1 was clay loam in texture that contained about $30 \%$ clay (below $0.002 \mathrm{~mm}$ ), $30 \%$ sand $(0.20-0.2 \mathrm{~mm})$ and $40 \%$ silt $(0.02-0.002 \mathrm{~mm})$, and the site- 2 was loam in texture that contained about $40 \%$ sand, $40 \%$ silt and $20 \%$ clay. The bulk densities of site- 1 were higher than site-2. The bulk densities of topsoil and sub soil in site-1 were 1.62 and $1.58 \mathrm{gcm}^{-3}$, while in site-2, the bulk densities of topsoil and subsoil were 1.52 and $1.40 \mathrm{gcm}^{-3}$, respectively. In site-1, the bulk density of plough pan layer was found higher $\left(1.91 \mathrm{~g} / \mathrm{cm}^{3}\right)$ than topsoil and subsoil. Salokhe et al. (1998) observed that the percentage reduction in bulk density increases with the increase of puddling which is a common practice in rice cultivation. Similar finding was found by Garg et al. (2000) who observed that puddling decreases bulk density.

The average percent soil moisture of both the sites ranged from 49.58 to $57.1 \%$ (Table 1). The soil moisture percentage in site 2 is higher than site 1 . The reason behind high moisture in site- 2 may be due to minimum tillage operation compared to site-1. Saltion and Mielniczuk (1995) found the highest moisture content where no tillage is practiced and lowest where conventional tillage is practiced. In site1, sub-soil moisture was found to be lower than topsoil. The lower moisture content in subsoil is due to the presence of plough pan layer. 
Table 1. Physical properties of soils of site- 1 and site- 2 .

\begin{tabular}{|l|c|l|c|c|l|}
\hline & $\begin{array}{c}\text { Soil depth } \\
(\mathrm{cm})\end{array}$ & Soil layers & $\begin{array}{c}\text { Bulk density } \\
\left(\mathrm{g} / \mathrm{cm}^{3}\right)\end{array}$ & Moisture (\%) & \multicolumn{1}{|c|}{ Texture } \\
\hline Site-1 & $0-10$ & Top soil & 1.62 & 50.96 & $\begin{array}{l}\text { Clay loam (30\% clay, 30\% } \\
\text { sand and 40\% silt) }\end{array}$ \\
\cline { 2 - 5 } & $12-15$ & Plough pan & 1.91 & 54.08 & \\
\cline { 2 - 5 } & $15-25$ & Sub soil & 1.58 & 49.58 & \\
\hline \multirow{3}{*}{ Site -2 } & $0-10$ & Top soil & 1.52 & 57.10 & $\begin{array}{l}\text { Loam (40\% sand, 40\% silt } \\
\text { and 20\% clay) }\end{array}$ \\
\cline { 2 - 5 } & $10-25$ & Sub soil & 1.40 & 53.50 & \\
\hline
\end{tabular}

\section{Chemical properties of soil}

The $\mathrm{pH}$ of all soil samples were found to be ranged between in 6.0 to 6.8 (Table 2). It has been found that topsoil of site-1 was slightly acidic, and the plough layer and sub-soil layer were neutral, whereas the topsoil of site-2 was neutral and subsoil was slightly acidic. Mazid et al. (1999) revealed that high tillage intensity that results in plough pan formation increase soil pH. However, Kruger (2004) did not find any difference in $\mathrm{pH}$ among no tillage, surface tillage and moldboard ploughing.

In site-1, the organic $\mathrm{C}$ content has been found higher in topsoil (1.36\%) and subsequently decreased in lower layers (Table 2). But in site-2, the $\mathrm{C}$ content of topsoil was found lower $(0.42 \%)$ than subsoil $(0.65 \%)$. The content of $\mathrm{C}$ is high where tillage practice is minimum (Rahman et al., 2003). The high content of organic $\mathrm{C}$ is due to the application of organic matter for the production of rice and other crops.

The concentration of $\mathrm{N}$ varied from $0.11 \%$ in topsoil of site- 1 to $0.02 \%$ in top-soil of site- 2 . The $\mathrm{N}$ content has been found higher in site-1 compared to site-2. Total $\mathrm{N}$ of different soil series of Bangladesh ranges from 0.05-0.22\% (Bhuiyan, 1994). Chowdhury (1995) observed that $\mathrm{N}$ content decreased with increasing the soil depth.

Table 2. Chemical properties of soils of site- 1 and site- 2 .

\begin{tabular}{|l|c|c|c|c|c|c|c|c|c|}
\hline & $\begin{array}{c}\text { Soil } \\
\text { depth } \\
(\mathrm{cm})\end{array}$ & $\begin{array}{c}\text { Soil } \\
\text { layers }\end{array}$ & $\mathrm{pH}$ & $\begin{array}{c}\text { Organic } \\
\mathrm{C}(\%)\end{array}$ & $\mathrm{N}(\%)$ & $\begin{array}{c}\mathrm{K}(\mathrm{mg} \\
\left.100 \mathrm{gm}^{-1}\right)\end{array}$ & $\begin{array}{c}\mathrm{P}(\mathrm{mg} \mathrm{kg} \\
\left.{ }^{1}\right)\end{array}$ & $\begin{array}{c}\mathrm{S}\left(\mathrm{mg} \mathrm{kg}^{-}\right. \\
\left.{ }^{1}\right)\end{array}$ & $\begin{array}{c}\mathrm{Zn}^{(\mathrm{mg}} \\
\left.\mathrm{kg}^{-1}\right)\end{array}$ \\
\hline \multirow{2}{*}{$\begin{array}{l}\text { Site } \\
-1\end{array}$} & $0-10$ & Top soil & 6.2 & 1.36 & 0.11 & 0.13 & 8.70 & 24.30 & 0.64 \\
\cline { 2 - 10 } & $12-15$ & $\begin{array}{c}\text { Plough } \\
\text { pan }\end{array}$ & 6.7 & 0.79 & 0.07 & 0.11 & 7.10 & 21.70 & 0.60 \\
\cline { 2 - 10 } & $15-25$ & Sub soil & 6.6 & 0.65 & 0.05 & 0.09 & 8.70 & 23.30 & 0.40 \\
\hline \multirow{2}{*}{\begin{tabular}{l} 
Site \\
\cline { 2 - 10 }
\end{tabular}} & $0-10$ & Top soil & 6.8 & 0.42 & 0.02 & 0.08 & 9.00 & 18.70 & 0.24 \\
\cline { 2 - 10 } & $10-25$ & Sub soil & 6.0 & 0.65 & 0.05 & 0.12 & 8.30 & 21.80 & 0.67 \\
\hline
\end{tabular}

The average level of available $\mathrm{K}$ for both the sites

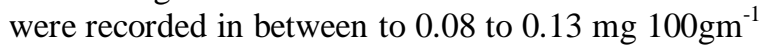
(Table 2). Like $\mathrm{N}$, the highest concentrations of $\mathrm{K}$ were found in topsoil layer of site- 1 and in subsoil layer of site-2. Available potassium increased significantly in the top layer of shallow tilled soil, but not within 10-20 cm layer compared to ploughed soil (Comia et al., 1994). The high content of $\mathrm{K}$ is due to the application of potash in agricultural field of site-1 for the production of rice and other crops. 
The average level of available $\mathrm{P}$ for both the sites were recorded in between to 7.10 to $9.00 \mathrm{mg} \mathrm{kg}^{-1}$. Whereas the concentrations of $\mathrm{N}$ and $\mathrm{P}$ were found lowest in topsoil layers of site -2 , the concentration of $\mathrm{P}$ was found lowest in sub-soil layer. In site-1, the phosphorus concentrations in top and sub-soil layers were same $\left(8.7 \mathrm{mg} \mathrm{kg}^{-1}\right)$ and plough pan layer contained comparatively lower amount of P $(7.1 \mathrm{mg}$ $\mathrm{kg}^{-1}$ ). Feiziene et al. (2006) reported that the concentration of phosphorus is highest in $0-10 \mathrm{~cm}$ soil depth and decreases with soil depth. Total $\mathrm{P}$ decreases with the increase of depth in soil subject to minimum tillage (Singh et al., 1998).

The average concentration of available $\mathrm{S}$ in site-1 varied from 21.70 to $24.30 \mathrm{mg} \mathrm{kg}^{-1}$ and in site-2, it varied from 18.70 to $21.80 \mathrm{mg} \mathrm{kg}^{-1}$. In case of $S$, the highest concentration was found in top-soil layer of site-1 but lowest in top-soil layer of site-2 (Table 2). The concentration of $\mathrm{S}$ in sub-soil layer of site- 2 was found higher compared to topsoil layer. The plough pan layer of site-1, however, contained lower concentration of $S$ than top and sub-soil layers. The presence of plough pan results in reduced loss of $\mathrm{S}$ by leaching in site-1. In site-2, higher $S$ content in subsurface soil compared to surface soil is due to leaching through soil, where no compact layer was found. Similar finding has been found by Hussain et al. (1999).

The average concentration of available $\mathrm{Zn}$ ranged from $0.24 \mathrm{mg} \mathrm{kg}^{-1}$ in topsoil layer of site-2 to $0.67 \mathrm{mg}$ $\mathrm{kg}^{-1}$ in topsoil layer of site-1 (Table 2). Data revealed that $\mathrm{Zn}$ concentration decreased from top to sub soil layer in site- 1 and increase in case of site- 2 . $\mathrm{Zn}$ ions

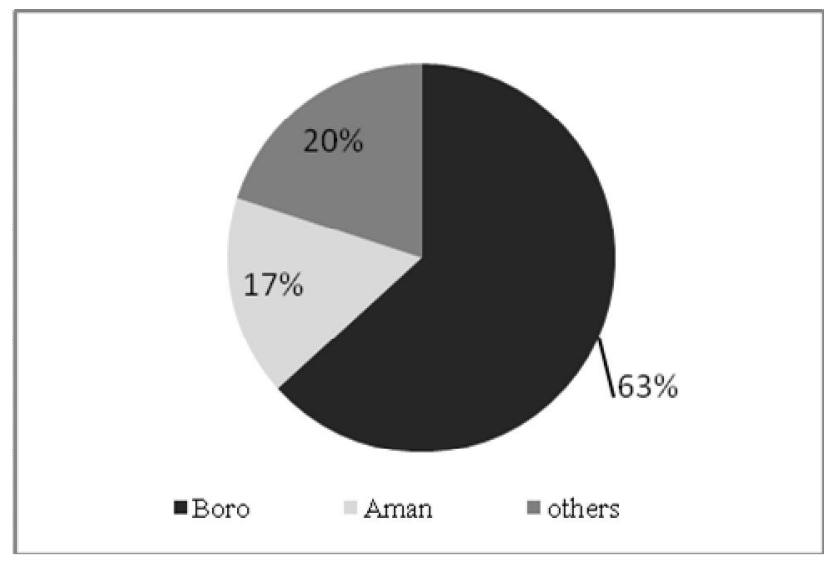

Fig. 1. Major crops grown in the area.

The repeated ploughing of soil in a same depth by heavy machineries for long years may cause plough pan formation. About $76.7 \%$ respondents have idea
$\left(\mathrm{Zn}^{2+}\right)$ are held on the surface of clay and organic matter particles. Soil organic matter holds $\mathrm{Zn}$ in a cheated form. Lorenz et al. (2000) observed that soils high in clay and organic matter has higher adsorptive capacities and higher bonding energies for $\mathrm{Zn}$ than sandy soils low in organic matter. The higher content of clay and organic matter in site-1 was responsible behind higher concentration of $\mathrm{Zn}$ in site-1.

\section{People's perception}

The study area was selected for more possibility to identify plough pan formation on sub-soil due to vast rice cultivation. In the studied areas rice was cultivated for most of the growing periods. The respondents of the survay included $83.3 \%$ male and $16.7 \%$ female. It was found that about $93.3 \%$ of respondents was unknown about plough pan formation and only $6.7 \%$ has little concept about subsoil compaction. To understand the possible causes of ploughpan formation, various information were collected on cropping pattern of the area, machines used for tillage practices and so on. From the survey, it was revealed that cropping pattern is a major cause behind subsoil compaction. Much of the area $(63.3 \%)$ was found under boro, $16.7 \%$ area under aman and $20.0 \%$ was used for other crops such as jute, mustard, potato, onion etc. (Fig. 1). For the cultivation of rice, different heavy machineries are used by the farmers. It was found that the farmers used mainly normal tractors. A small percentages used Mahindra (kind of tractor) and lighter tillage machineries. The percentages of different tillage machines used by farmers are given in Fig. 2.

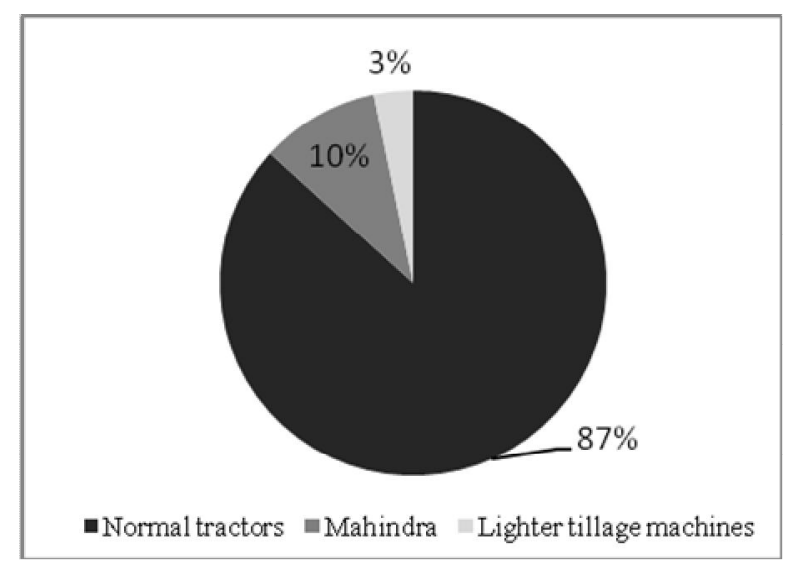

Fig. 2. Different tillage machines used in the area.

about importance of crop rotation and $23.3 \%$ have no idea about the said. 


\section{Conclusions}

The study has been conducted the impact of plough pan on soil environment especially through rice cultivation. Nutrient status in study area is very poor where crop rotation practices are extremely important increasing soil productivity. Use of bio-fertilizer must be applied to reduced soil compaction and increase soil health condition, and the Organic crop rotation practice could reduce plough pan reformation in the study areas.

\section{References}

Bertolino, A. V. F. A., N. F. Fernandes, J. P. L. Miranda, A. P. Souza, M. R.S. Lopes, F. Palmieri. 2010. Effects of plough pan development on surface hydrology and on soil physical properties in Southeastern Brazilian plateau. Journal of Hydrology. 393 (1-2). 94104.

Bhuiyan, N. I. 1994. Co-ordinated project on potassium. Progress report (1987-88), BARI, Joyedebpur, Gazipur. pp.1-45.

Bouyoucos, G. J. 1927. The hydrometer as a method for the mechanical analysis of soils. Soil Sci. 23: 343-353.

Chowdhury, A. H. 1995. To study the physical and chemical properties of two AEZ of Bangladesh under three cropping patterns, M.S. Thesis, Dept. of Soil Sci, BAU, Mymensing. pp. 1-95.

Comia, R. A., M. Stenberg, P. Nelson, T. Rydberg, I. H. Êkansson. 1994. Soil and crop responses to different tillage systems. Soil Tillage Res. 29: 335-355.

Feiziene, D, V. Feiza. and I. Deveikyta. 2006. Reduced tillage in spring and influence on soil chemical properties. Zemdirbyste Mokslo. 93(3): 56-62.

Garg, R. N., D. K. Das, A. M Sharma, M. joydeep, S.Gurachran, j. Mukherjee, and G. Singh. 2000. Soil physical properties and paddy yield as influenced by puddling methods. Annals. Agril. Res. 21:(2): 192-198.

Huq, S. M. I. and M. D. Alam. 2005. A Handbook on analyses of soil, plant and water. BACER-DU, University of Dhaka, Bangladesh. PP. 13-40.

Hussain, I., K. R. Olson and S. A. Ebalhar. 1999. Long term tilage effects on soil chemical properties and organic matter fractions. Soil Sci. Soc. Am. J. 63: 1335-1341.
Islam, M. S., A. S. M. S. Karim, M. S. Hossain and M. M. Masud. 2005. Tillage and Mulch effects on some soil physical properties and yield of wheat in shallow red brown terrace soils of Bangladesh. Sarhad J. Agric. 21 (4): 655-665.

Jackson, M. L. 1967. Soil chemical analysis. Prentice Hall of India pvt. Ltd., New Delhi. 498p.

Jeyasree, G., and M. S. Rao. 2005. Effect of tillage with organic amendments on soil physical environment,organic carbon and yield of rain fed castor in alfisols. Annals Agric.Bio. Res. 10 (1): 7-10.

Kruger, H. R. 2004. Tillage systems and variation in the chemical properties of an Entic Haplustoll. Ciencia de Suelo. 14 (5): 53-55.

Mazid, M. A., T. H. Khan and S. Rahman, 1999. Tillage and nitrogen effects on soil properties,dynamics of soil nitrogen and wetland rice yield. Bangladesh J. Sci.Tech. 1: 123-132.

Lorenz, S. E., R. E. Hamon, P. E. Holm, H. C. Domingues, E. M. Sequeiria, T. H. Christensen, S. P. McGrath. 2000. Cadmium and zinc speciation in heavy metal contaminated soils from six European countries. Bioresour. Tech. 71 (3): 254-259.

Piper, C. S. 1950. Soil and plant analysis. Adelaid Univ. Hassel Press, Australia. 368p.

Rahman, M. H., A. Tanaka and S. Hoque. 2003.Long term effects of tillage and physicochemical properties of modified Andisol of North-East Honshu Island. Soil Sci. plant Analy. 34(11-12): 1743-1757.

Salokhe, V. M., M. H. Mials and M. Holi. 1998. Puddling effects on some physical properties of Bangkik clay soil. Soils and Ferts. 57(3): 278.

Saltion, J. C. and J. Mielniezeuk. 1995. Relationship between tillage.temparature and moisture in a dark red podzokic soil eldoradosul. Revista brasileia decienciaadoslo. 19(2): 313-319.

Singh, P. K. C., R. Aipe, S. N. Prasad, S. Sharma, P. Singh. 1998. Relative effect of zero and conventional tillage on growth and yield of wheat and soil fertility under rice-wheat cropping system. Indian J. Agron. 443(2): 204-207.

SRDI ( Soil Resource Development Institute ). 1994. Land and soil resource indicator, Ministry of agriculture Government of the People's Republic of Bangladesh, Dhaka . 42p.

Subbaiah, B. V. and G. L. Asija. 1956. A rapid procedure for determination of available nitrogen in soils. Curr. Sci. 25: 259-260. 


\section{J. Environ. Sci. \& Natural Resources, 5(1): 289-294, 2012}

Tsimba, R., A. Hussain and R. Ndlovu. 1999. Relationship between depth of tillage and soil physical characteristics of sites farmed by samllholders in Mutako and Chinyika in Zimbabwe. Aresearch book of the Animal Traction Network our Eastern and Southern Africa (ATNESA). Harare, Zimbabwe. 173p.
USDA (United States Department of Agriculture). 1951. Soil Survey Manual. Soil Survey Staff, Bureau of Plant Industry, Soils and Agricultural Engineering, United States Department of Agriculture, Washington. Handbook 18. 205p. 